\title{
Farms expectations concerning individual projects in mountain areas of Tlemcen province (Algeria)
}

\author{
Mourad Hattab*, Abdelaziz Gaouar
}

University of Tlemcen, Tlemcen, Algeria

*Corresponding author, e-mail: htb83-agromourad@hotmail.fr

\begin{abstract}
The present work aims to analyze the expectations of farms concerning the Proximity Projects of Integrated Rural Development (PPDRI) which could be implemented by the Algerian government in rural areas in general, and in mountainous areas in particular. For that, 122 farms have been surveyed in three mountainous regions (Ain Fezza, El Gor and Sidi Djilali) belonging to the mountains of Tlemcen which are north-west of Algeria. The results obtained showed that expectations of farms, in terms of individual projects desired to be made, differ from one region to another. Moreover, the heads of surveyed farms retain a remarkable awareness vis-à-vis agricultural projects that are better suited to the potential of their mountainous areas. In addition, the development of certain high-value agricultural activities which appear despised by many farms and can contribute in a significant way to improve their income sources, requires from the start a considerable improvement of technical assistance proves insufficient in these disadvantaged areas. Finally, public authorities should know good value the projects formulated by farms, and readjust its funding according to the particularities of these areas which are poor and characterised by difficult natural constraints.
\end{abstract}

Keywords: Agricultural activities, natural constraints, rural areas, surveys

\section{Fazendas expectativas relativas a projectos individuais em zonas de montanha da província de Tlemcen (Argélia)}

\section{Resumo}

O presente trabalho tem por objetivo analisar as expectativas de fazendas sobre os Projectos de Proximidade de Desenvolvimento Rural Integrado (PPDRI) que poderia ser implementado pelo governo argelino em áreas rurais em geral, e em áreas montanhosas, em particular. Para isso, 122 fazendas foram pesquisados em três regiões montanhosas (Ain Fezza, El Gor e Sidi Djilali) pertencentes às montanhas de Tlemcen que são noroeste da Argélia. Os resultados obtidos mostraram que as expectativas de fazendas, em termos de projectos individuais desejadas para ser feita, diferem de uma região para outra. Além disso, os chefes de fazendas pesquisadas manter uma consciência notável vis-à-vis projectos agrícolas que são mais adequadas para o potencial de suas áreas montanhosas. Além disso, o desenvolvimento de certas actividades agrícolas de alto valor que parecem desprezados por muitas fazendas e podem contribuir de forma significativa para melhorar as suas fontes de renda, exige desde o início uma melhoria considerável da assistência técnica se revelar insuficiente nestas áreas desfavorecidas. Finalmente, as autoridades públicas devem saber bom valor os projetos formulados por fazendas, e reajustar o seu financiamento de acordo com as particularidades dessas áreas que são pobres e caracterizada por constrangimentos naturais difíceis.

Palavras-chave: atividades agrícolas, condicionalismos naturais, áreas rurais, levantamentos 


\section{Introduction}

For years, rural territories in Algeria were managed with methods characterized by centralization, which led to marginalization and limited development of these territories especially that are landlocked. With the advent of the Rural Renewal Policy (PRR) in 2006, public intervention in rural areas has been completely changed; after being down and sectoral, it became horizontal, proximity, bottom up, integrated, participatory and decentralized (MADR, 2005; Souidi \& Bessaoud, 2011; Chaib \& Baroudi, 2014). The PRR targeting primarily the areas where production conditions are the most difficult for farmers (mountain areas, steppes, oases of the Sahara), is structured around four main programs. The first concerns the modernization of villages: it is about improving the quality and conditions of life in rural areas by providing the rural population with amenities that are usually attributed to the towns and cities. The second program is the diversification of economic activities: local economy, trade, rural tourism, crafts, promotion of local products, etc. The third program concerns protection and enhancement of natural resources: forest, steppe, oases, mountains, coastline, but also farmland. Whereas the fourth program is linked to the protection and enhancement of the tangible and intangible rural heritage. A transverse axis, has been also created: It is about the human capacity-building and technical assistance program (PRCHAT) by training of actors in the administration, elected officials, civil society, and the involvement of teaching, research, and international cooperation (Bessaoud \& Montaigne, 2009; MADR, 2010).

These programs must be carried out under participatory and proximity rural development approach, which is formalized by the tool named "Proximity Projects of Integrated Rural Development" (PPDRI). This participatory approach should reserve a prominent place to the local population in the design, the implementation and the management of these projects.

According MADR (2015), remarkable results have been achieved until that date in improving living conditions of rural population.
However, some studies in this field reported that involvement of the rural population in PPDRI is not yet fully accomplished, and the decentralization of decision remains unfinished (Kharchi, 2010; Zaghib, 2010; Amzal, 2011; Rahmouni, 2013; Baghdad, 2015). For this reason, we want to ask ourselves if the expectations of the rural population, which are especially related to individual projects, really deserve to be fully validated by local authorities.

To this end, since agriculture is the main activity in rural areas, this work which was conducted in mountainous areas belonging to the mountains of Tlemcen, aims to analyze the real expectations of farms in terms of individual projects wanting to be implemented under the PPDRI in order to evaluate the link between these expectations and potentials of the regions studied that encourage or discourage the implementation of these projects.

\section{Material and Methods}

The use of farmers surveys is paramount action in any approach to study a given environment rural. For that purpose, the working method adopted is to conduct surveys, during the year 2014-2015, on farms in three mountainous regions (Ain Fezza, El Gor and Sidi Djilali) belonging to the mountains of Tlemcen which are north-west of Algeria (Figure 1). So we have chosen one region located in the northern part of this mountain range and two other regions in the south, and that to see the effect of exposure on our study.

The tool of these surveys is a questionnaire which is formulated and designed in a way that the interviewee, after a brief characterization of the current situation of his farm, can pronounce on the projects that he would be carried concerning production activities that he currently practices or he wishes to introduce in the near future.

To characterize the current situation of the surveyed farms, the questionnaire concerned the following points: the annual precipitation which falls in each region studied; the slope of the surveyed farms plots; the farms size expressed in hectares and divided into classes; water resources used for irrigation; and finally production systems practiced by farms. 
For the second part regarding expectations of farms, the questionnaire was formulated around individual projects which have a relation with the following points: land improvements; hydroagricultural projects; fruit plantations; cereal and fodder crops; vegetable crops and pulses; mechanization and animal traction; livestock projects (sheep, cattle and goat); infrastructure for livestock; poultry farming; beekeeping; and finally funding for desired projects of the surveyed farms.

The surveyed sample has grouped 122 farms which are distributed in the three regions studied as follows: Ain Fezza 34 farms; El Gor 53 farms; Sidi Djilali 35 farms.

These surveyed farms were chosen in a way to cover as far as possible the territory of the study regions in order to highlight all the factors that determine their desired projects. Equally, the person to be interviewed was the head of the farm, so this is the one who takes charge of the management and especially the decision about the investment.

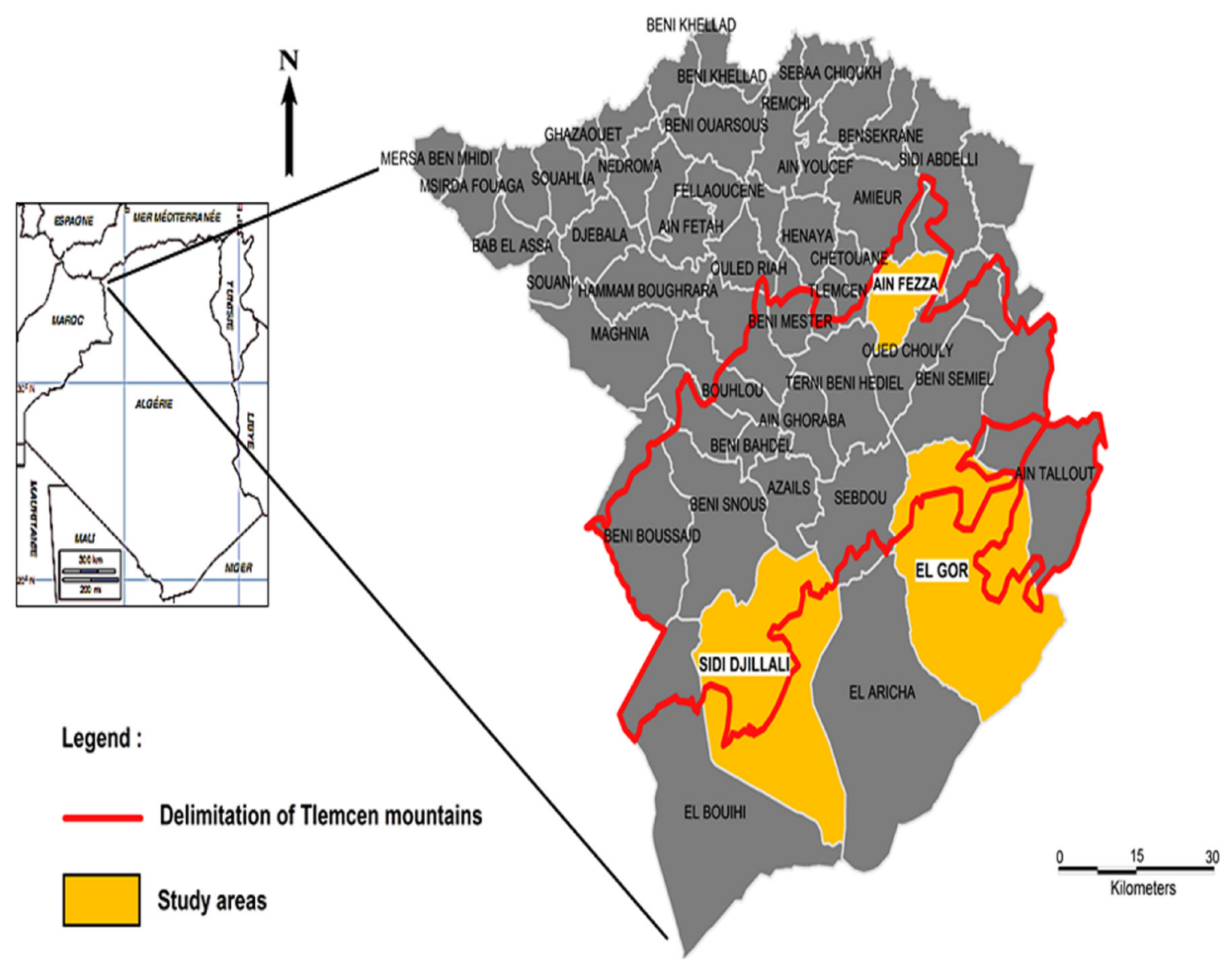

Figure 1. Location of the three study areas in the mountains of Tlemcen

\section{Results and Discussion}

Current situation of the surveyed farms

The analysis of the current situation of the surveyed farms, according to table 1, shows that there is a visible contrast between each study area although they belong to the same mountain range. At Ain Fezza, northern exposure of the mountains of Tlemcen, farms are mostly small in size and also contain plots locating on an escarpment lands that are difficult to use. It should be noted that the classes of land slope we have adopted here were those defined by BNEDER (2006). Furthermore, water availability which appears sufficient in this area, has allowed to farms the development of a livelihood strategy based mainly on crop diversification, especially vegetables and fruit trees.

However, El Gor and Sidi Djilali, southern exposure of the mountains of Tlemcen, are two steppe regions where farms have fairly large sizes and are mostly located on a piedmonts and valleys, of which slope is highly moderate 
or absent. Acute water deficit in these two regions with an arid climate, has forced many farms to practice usually a cereal monoculture which is conducted in extensive and combined especially with sheep farming.

It is noted that the common point between the three regions studied, is the existence of undeveloped agricultural activities such as beekeeping and poultry, despite the potential in these areas that seem favourable to development of these activities.
So we want, with this brief diagnosis of the current situation of farms we surveyed in the three study areas, to highlight the factors that will allow us, as we shall go on to examine, to better understand the reasons made the heads of farms enthusiastic to some agricultural projects at the expense of others. The expectations of agricultural development formulated by the surveyed farms are presented as specialized projects (land, production systems, mechanization, etc.).

Table 1. Current situation of the surveyed farms in the three regions studied

\begin{tabular}{|c|c|c|c|}
\hline \multirow{2}{*}{ Parameters } & \multicolumn{3}{|c|}{ Study regions } \\
\hline & Aïn Fezza & El Gor & Sidi Djilali \\
\hline \multirow[t]{2}{*}{ Annual precipitation } & $+400 \mathrm{~mm}$ & $-300 \mathrm{~mm}$ & $-300 \mathrm{~mm}$ \\
\hline & \multicolumn{3}{|c|}{ Rate of the surveyed farms (\%) } \\
\hline $\begin{array}{c}\text { Slope of the farm plots } \\
-0 \text { to } 3 \% \\
\text { - } 3 \text { to } 12,5 \% \\
\text { - } 12,5 \text { to } 25 \%\end{array}$ & $\begin{array}{l}97 \\
53 \\
65\end{array}$ & $\begin{array}{l}100 \\
17 \\
00\end{array}$ & $\begin{array}{l}100 \\
37 \\
31\end{array}$ \\
\hline $\begin{array}{l}\text { Size of farms (ha) } \\
\text { ]0-5] } \\
\text { ]5-10] } \\
\text { ]10-20] } \\
\text { ]20-50] } \\
>50\end{array}$ & $\begin{array}{l}50 \\
23,52 \\
8,82 \\
14,7 \\
2,94\end{array}$ & $\begin{array}{l}1,88 \\
16,98 \\
30,18 \\
32 \\
18,8\end{array}$ & $\begin{array}{l}17,14 \\
8,57 \\
20 \\
34,28 \\
20\end{array}$ \\
\hline $\begin{array}{l}\text { Irrigation sources } \\
\text { - Any } \\
\text { - Well } \\
\text { - Drilling } \\
\text { - Resurgences } \\
\text { - Hillside catchment reservoirs }\end{array}$ & $\begin{array}{l}2,94 \\
5,88 \\
50 \\
52,94 \\
00\end{array}$ & $\begin{array}{l}96,22 \\
1,88 \\
00 \\
00 \\
1,88\end{array}$ & $\begin{array}{l}88,57 \\
00 \\
11,42 \\
2,85 \\
5,71\end{array}$ \\
\hline $\begin{array}{l}\text { Production systems practiced } \\
\text { - Cereals } \\
\text { - Fodders } \\
\text { - Vegetable crops } \\
\text { - Pulses } \\
\text { - Fruit trees } \\
\text { - Sheep farming (average number) } \\
\text { - Cattle farming (average number) } \\
\text { - Goat farming (average number) } \\
\text { - Poultry farming } \\
\text { - Beekeeping }\end{array}$ & $\begin{array}{l}42 \\
52 \\
98 \\
11 \\
88 \\
14,70(11) \\
26,47(04) \\
02,94(02) \\
14,70 \\
05,88\end{array}$ & $\begin{array}{l}100 \\
100 \\
00 \\
00 \\
07 \\
32(87) \\
30,18(08) \\
26,41(19) \\
09,43 \\
00\end{array}$ & $\begin{array}{l}93 \\
93 \\
12 \\
00 \\
63 \\
40(98) \\
22,85(07) \\
11,42(25) \\
31,42 \\
14,28\end{array}$ \\
\hline
\end{tabular}

Land improvement projects

Overall, according to Figure 2, land improvement projects interest the majority of the surveyed farms. In fact, although the Algerian state does not consider sharecropping and leasing land as projects which could be financed, these operations, with purchasing land, reflect the interest taken by many farms to expand their agricultural land at Ain Fezza particularly where the fragmentation of severel farms in small sizes limits strongly its productivity as it was confirmed by several authors (Niroula \& Thapa, 2005; Austin et al., 2012; Jia \& Petrick, 2013). This interpretation is also consolidated by the fact that some farms are also interested in trenching and destoning projects to develop their parcels remaining until now marginalized and locating especially on an escarpment lands.

In addition, projects of agricultural land extension are highly achievable if we know that the State supports the projects of the creation of new farms by developing marginalized 
agricultural land pertaining to the State private domain and to the private property (MADR, 2011).

In general, exploitation of agricultural land in mountain areas is a delicate operation that should be well managed in order to achieve two objectives, optimize land productivity, and sustainably protect these fragile ecosystems.

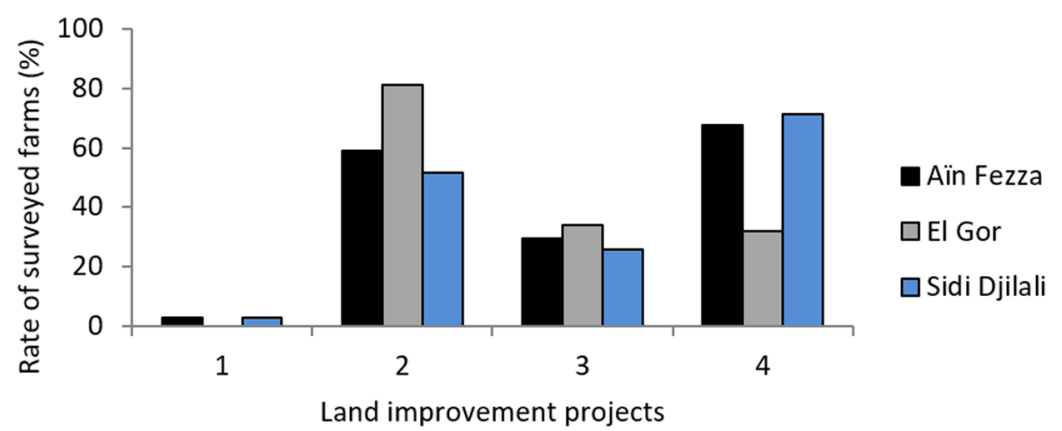

Figure 2. Rate of surveyed farms according to their desired land improvement projects. $\mathbf{1}=$ No project. $\mathbf{2}$ = Expand the agricultural land by sharecropping and/or leasing. $\mathbf{3}=$ Purchasing land. $\mathbf{4}$ = Enhancement by trenching and destoning.

Hydro-agricultural projects

At Ain Fezza, irrigation is well developed because of the wealth of water resources that characterizes this region. That is why farms are very enthusiastic about the acquisition of irrigation equipment or the renewal those that are worn, in order to have a better mobilization of water for irrigation (Figure 3). They are also interested in improvement the state of the existing water source by increasing the depth of their drillings to raise its flows.

This very particular interest that accorded to hydro-agricultural projects in Ain Fezza can be explained by the key role that irrigation plays on productions stabilization of the surveyed farms and on diversification of their crops to face a random climate. So, Irrigation allows a crop diversification, an improvement of farms productivity and a production stabilization. It also helps to reduce the hazards of climate change (FAO, 2004; Madramootoo \& Fyles, 2010; Angeliaume, 2011; Benniou \& Van Damme, 2013). However, the amazing thing we have detected was that the two regions of El Gor and Sidi Djilali although they suffer from an acute water deficit, the majority of farms do not give great importance to hydro-agricultural projects. They seem to be content with what it gives them the combination of extensive grain farming with livestock. This trend can be justified by the conviction of the heads of farms on the scarcity of groundwater resources which can not mobilize enough water to create irrigated areas. In fact, prospects of hydrogeological formations which hit the southern foothills of the mountains of Tlemcen revealed that groundwater resources were still low (Bensaoula et al., 2005; Bensaoula et al., 2012.).

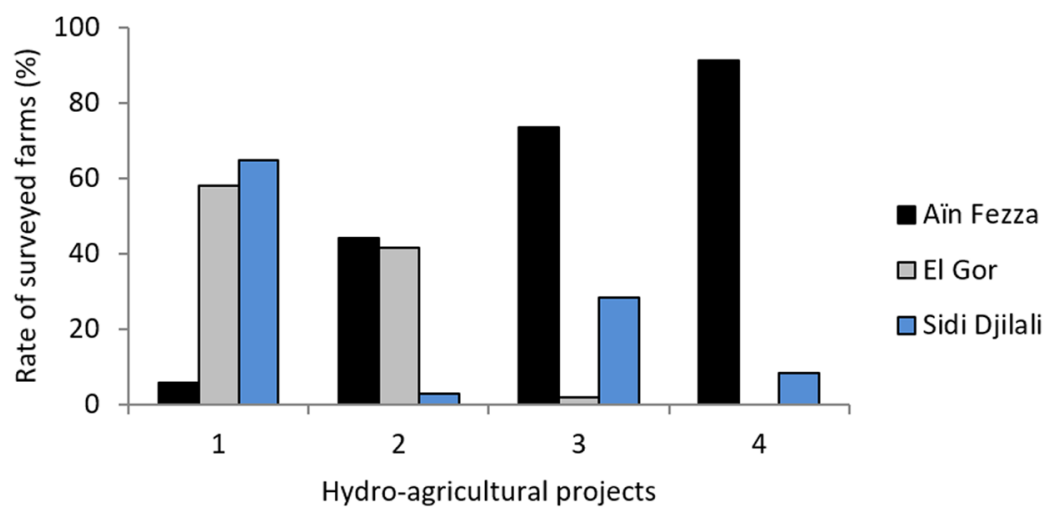

Figure 3. Rate of surveyed farms according to their desired hydro-agricultural projects. $1=$ No project. $\mathbf{2}$ = Drilling Implantation. $\mathbf{3}$ = Improvement the state of the existing water source. $\mathbf{4}=$ Acquisition or renewal of equipment. 
Fruit plantations projects

It is entirely logical, according to Figure 4, that the rustic fruit species such as olives, almonds and figs very intereste farms because it adapt very well to the climate of the regions studied especially at El Gor and Sidi Djilali where the introduction of other fruit species, with high water needs, in these two arid regions is an unprofitable project. This expectation is in accordance with fruit plantations carried out until that date in Algeria as part of PPDRI, where the olive tree represents $80 \%$ of the total area planted with fruit trees (MADR, 2015a). Olive tree, according Sofo et al. (2008), can effectively tolerate drought that characterizes Mediterranean climates.

Note also that the region of Ain Fezza is very conducive to fruit plantations development of all species confounded because irrigation water is sufficiently available. For this, farms should be encouraged to such projects especially cherry plantation which is very suitable to the configuration of this mountainous area; it is a high value-added fruit species which is in high demand in Algerian markets.

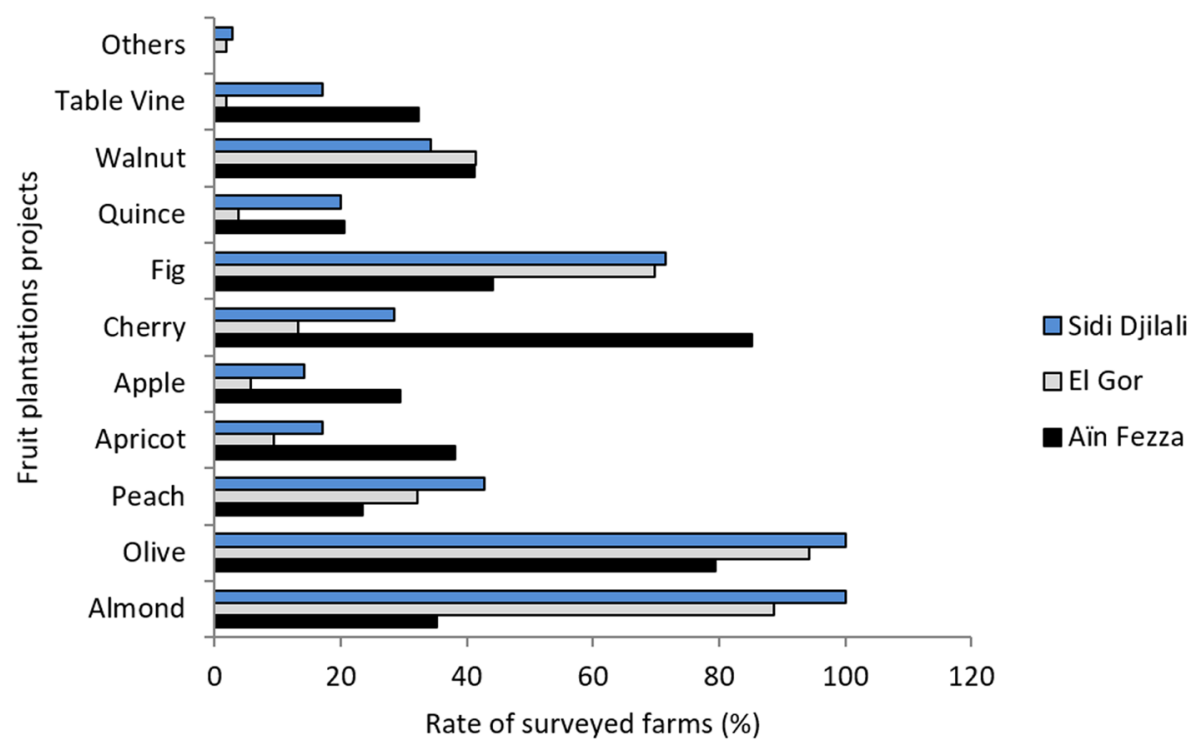

Figure 4. Rate of surveyed farms according to their desired fruit plantations projects

Projects of cereal and fodder crops

In El Gor and Sidi Djilali, the practice of livestock on a large-scale combined with farms having fairly large sizes located on moderate slopes, are two main factors made farms very interested to intensify even more cereal and forage crops (Figure 5A and 5B). In reality, the water deficit characterizing these two arid regions did not leave enough choice only for extensive production systems. Throughout the agricultural season, these extensive production systems are totally dependent on a low and erratic annual precipitation, which has significantly compromised the stability of crop yields and has therefore made it unprofitable. Indeed, in such circumstances, the bank credit-based financing for such projects proves unreliable. Logically, banks do not participate in any project only in case where they ensure the recovery of their funds, which is not the case in this situation.
At Ain Fezza, on the contrary, the practice of livestock just for family profit, the dominance of the agricultural land with small sizes mainly reserved for vegetable crops and fruit trees giving good yields, and the presence of many parcels on steep lands hindering mechanization, are the main causes preventing the majority of farms to vote positively for the development of cereal and fodder crops.

\section{Projects of vegetable crops and pulses}

To ensure stable and acceptable yields, vegetable crops and pulses are strictly related to a sufficient supply of irrigation water at least during critical periods of its growing cycles. This sine qua non condition is almost absent in areas suffering from water deficit such as the regions of El Gor and Sidi Djilali which do not even have the bare minimum of water resources to develop such crops. For this, according to Figures $5 \mathrm{C}$ 
A

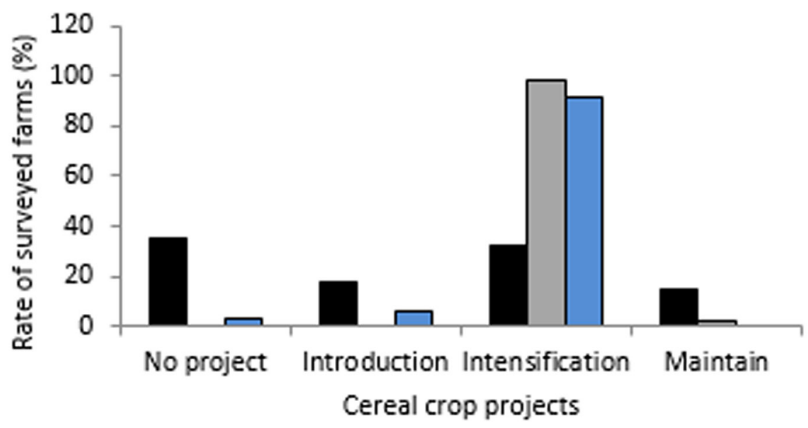

- Aïn Fezza

$\square$ EI Gor

口Sidi Djilali

B

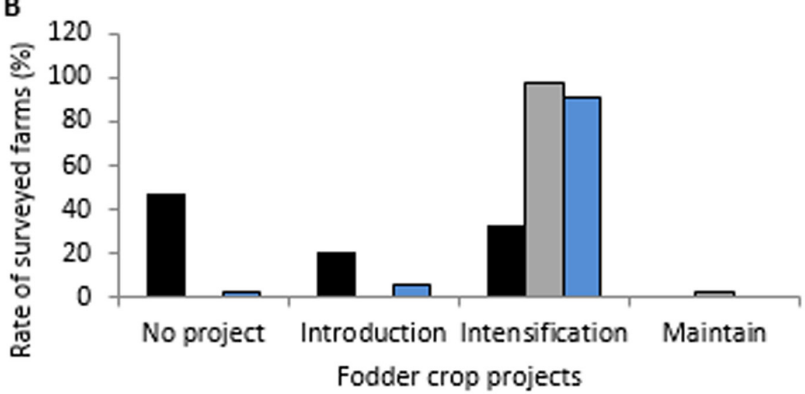

- Aîn Fezza

口El Gor

口Sidi Djilali

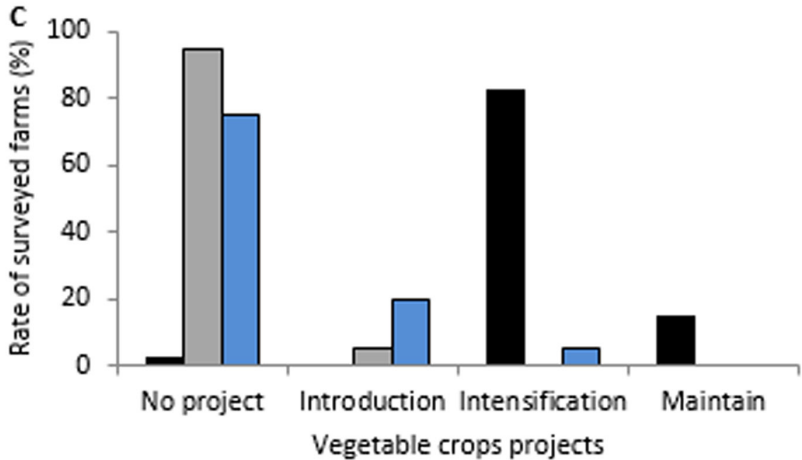

- Aïn Fezza

$\square$ EI Gor

口Sidi Djilali

Vegetable crops projects

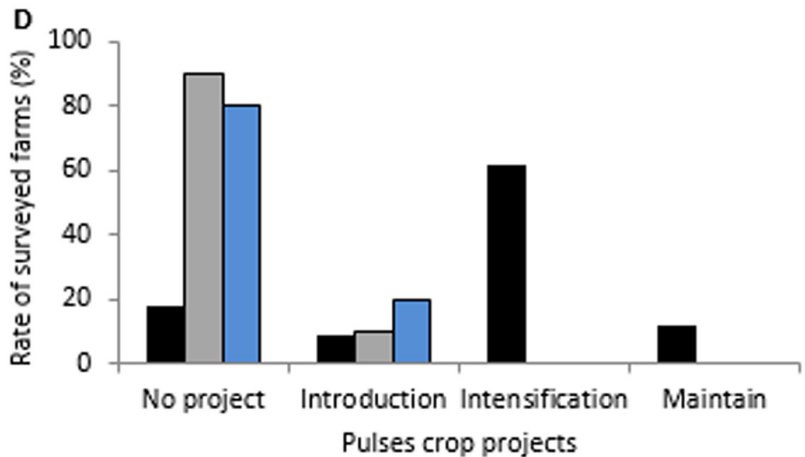

- Aïn Fezza

口EI Gor

$\square$ Sidi Djilali

Figure 5. Rate of surveyed farms according to their desired cereal (A), fodder (B), vegetable (C) and pulses (D) crop projects.

and $5 \mathrm{D}$, the heads of farms in these two regions appear very conscious of the impossibility to introduce these types of crops as production systems capable of providing some balance to these vulnerable farms.

However, the region of Ain Fezza is very conducive to development of vegetable crops and pulses having a very lucrative character. The water wealth, coming mainly from groundwater and surface water, gives a lot of guarantees to farms in this region to make widely successful this sort of projects which can generate very significant sources of income.

Moreover, in terms of production systems, 
it is noted that most of the projects formulated by the surveyed farms are in accordance with the potential of each region studied. So, the heads of farms, as such, retain an innovation and analysis capacity that the local authorities need to know value. This remark has been also observed by other authors in different regions of the world (Saito et al., 2006; Leitgeb et al., 2011)

\section{Projects of mechanization and animal traction}

According to the Figure 6, projects of mechanization much more interest farms in the regions of El Gor and Sidi Djilali where the farmlands on moderate slope are large enough to make this operation easier. Conversely, farms in Ain Fezza are attracted mainly by projects of animal traction constituting for them an alternative means to address the problems of small parcels and the steep farmlands hindering access for agricultural machinery.

Although very old, animal traction is not outdated and remained still current in many countries. The animals continue to contribute significantly to reduce the drudgery of agricultural works and various other activities, such as transportation. They thus help to improve working conditions and incomes in small farms (FAO, 2007; Lhoste et al., 2010; Belal et al., 2015).

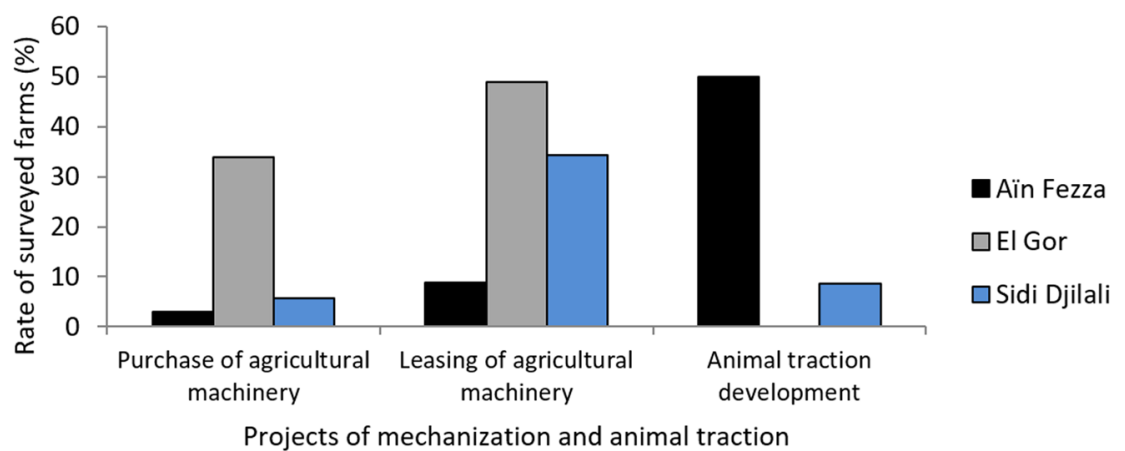

Figure 6. Rate of surveyed farms according to their desired projects of mechanization and animal traction

Livestock projects

The pastoral aspect characterizing the two steppe regions of El Gor and Sidi Djilali allowed farms to practice livestock on a large scale, this probably explains, according to Figures 7A, 7B and 7C, the very special interest which is granted to the development of this activity in these two regions. Livestock constitutes also an additional source of income to make up for low and irregular yields generally characterizing the extensive grain farming in arid regions with random climate (FAO, 2008; Vandamme et al., 2010).

However, in Ain Fezza, many farms do not yet seem truly appreciate the value of livestock practice as an additional source of income resulting from its marketable derivatives (meat, milk, wool, etc.). In this regard, the State participated to create 10000 family livestock units at the national level as part of PPDRI (MADR, 2015a). These efforts we have just mentioned reflect the possibility that farms can have to benefit from such project, particularly in Ain
Fezza.

Infrastructure projects for livestock

Closely related to the livestock activity which is practiced widely in the regions of $\mathrm{El}$ Gor and Sidi Djilali, many farms are pronounced positively about the infrastructure projects for livestock (Figure 8A). The very limited attention given to this type of projects in the region of Ain Fezza can be explained, on the one hand, by the lack of livestock tradition only for a family profit in this area, and on the other hand, by the smal size of many farmlands which has not helped to build this kind of infrastructure.

\section{Poultry projects}

Overall, according to Figure 8B, poultry projects interest many surveyed farms in the three regions studied. However, this type of project requires a bit heavy investment which is not accessible to most poor farmers in these regions. Whether broilers or laying hens, the success of this 

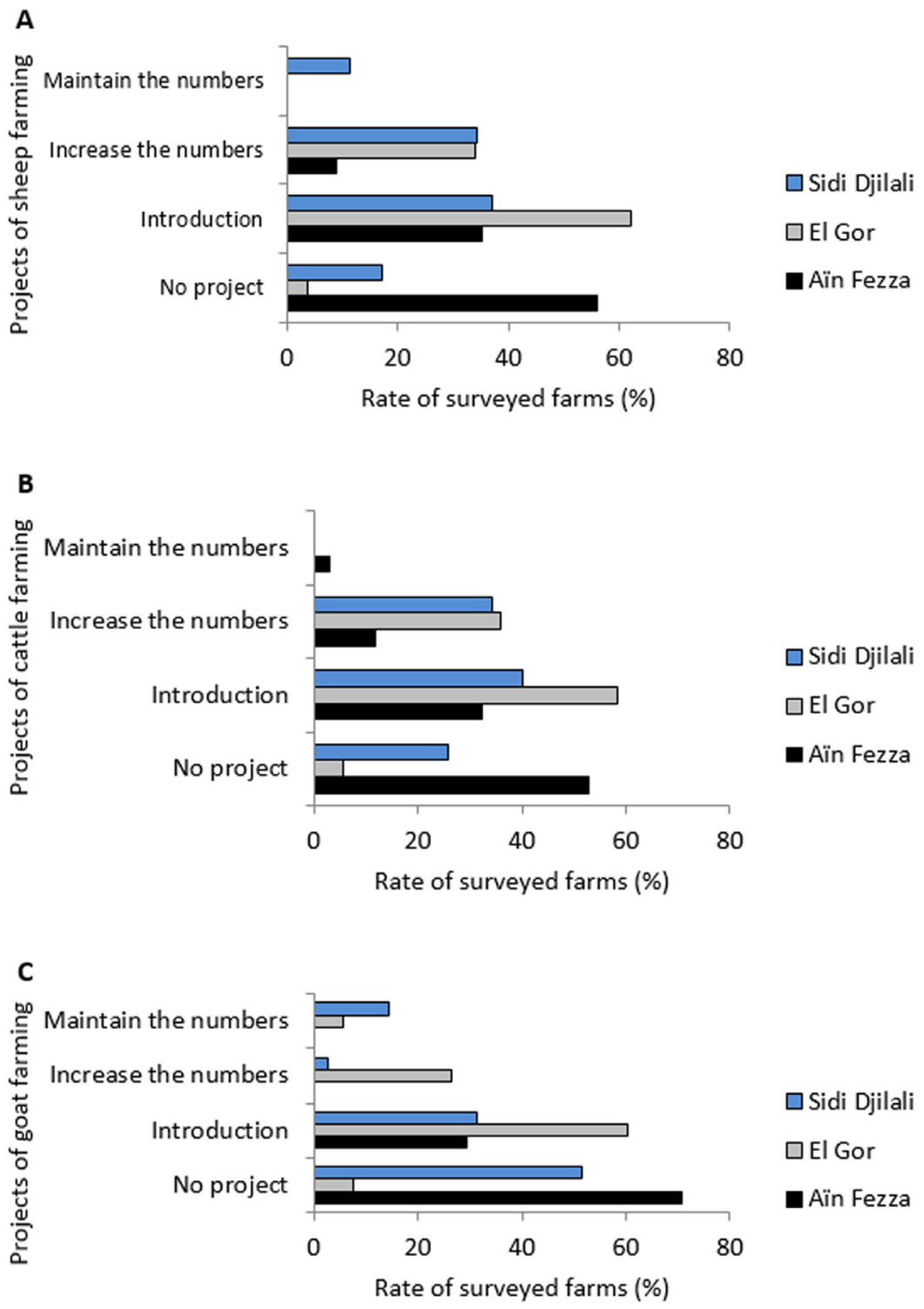

Figure 7. Rate of surveyed farms according to their desired sheep (A), cattle (B) and goat (C) farming projects.

type of livestock imperatively requires expensive material resources (well-developed buildings, thermal insulation, air renewal system, ventilation, etc.) and a livestock conduct which should be followed scrupulously. So, a significant funding is an essential operation to develop this activity in mountain areas.

\section{Beekeeping projects}

Despite the acceptable interest which is given to beekeeping by some farms especially in Sidi Djilali, some others at El Gor and Ain Fezza are, however, little incentive to invest in this kind of activity (Figure $8 \mathrm{C}$ ). The know-how constitutes, according to Figure 9, the biggest obstacle hindering realization and development of beekeeping projects.

Technical assistance seems, therefore, insufficient in these mountainous areas. Strengthening these areas by qualified technical staff could significantly improve the know-how of farmers and change, consequently, their 

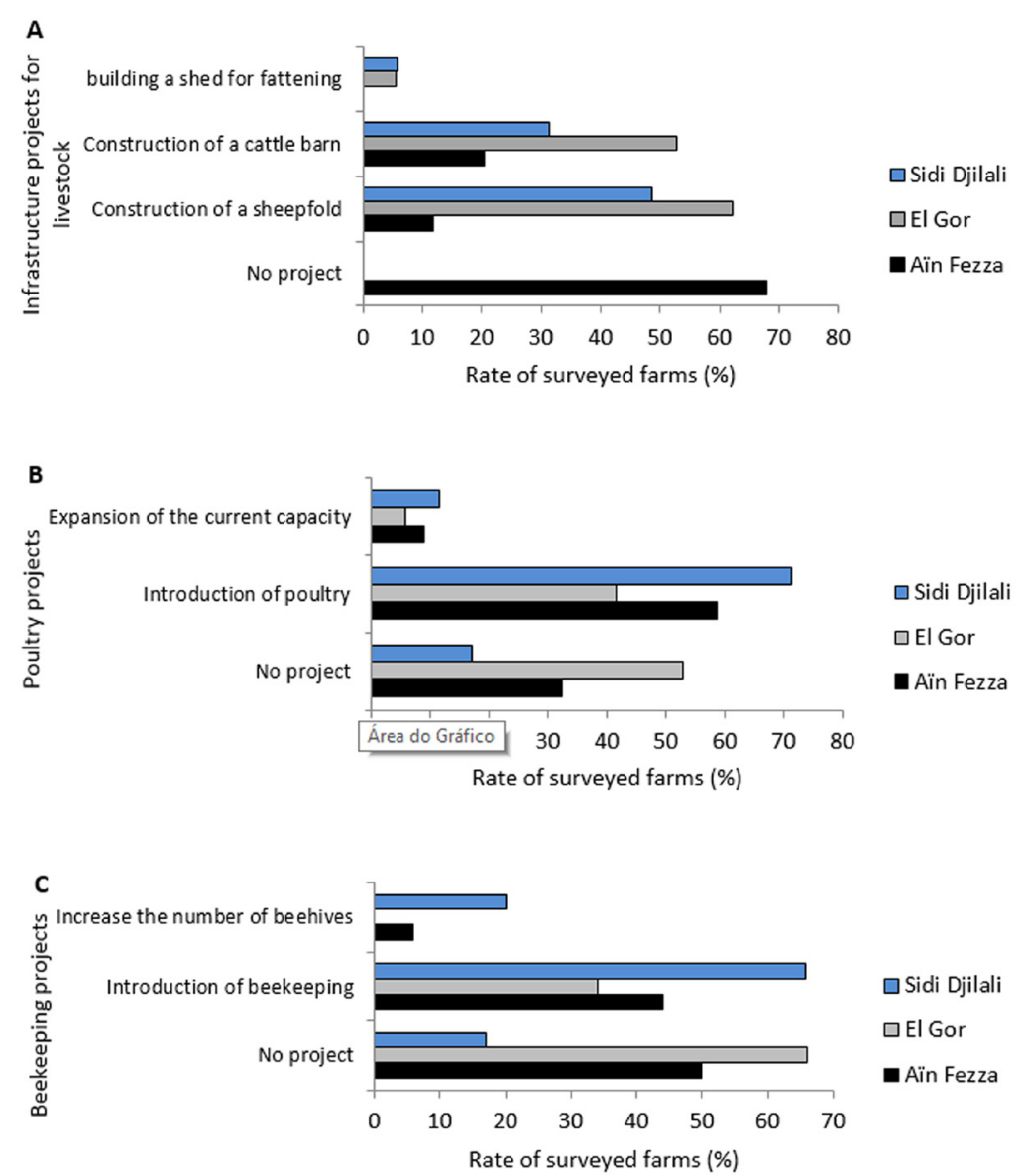

Figure 8. Rate of surveyed farms according to their desired infrastructure projects for livestock (A), desired poultry (B) and beekeeping projects.

expectations about some agricultural activities not yet mastered. In this context, we would like to mention here the remarkable efforts of state powers which have never ceased since the implementation of the program of human capacity building and technical support to producers (PRCHAT) as part of the Agricultural and Rural Renewal Policy (MADR, 2015b). However, it appeared from this study that the efforts of the State just mentioned have not yet attained some marginalized mountain areas.

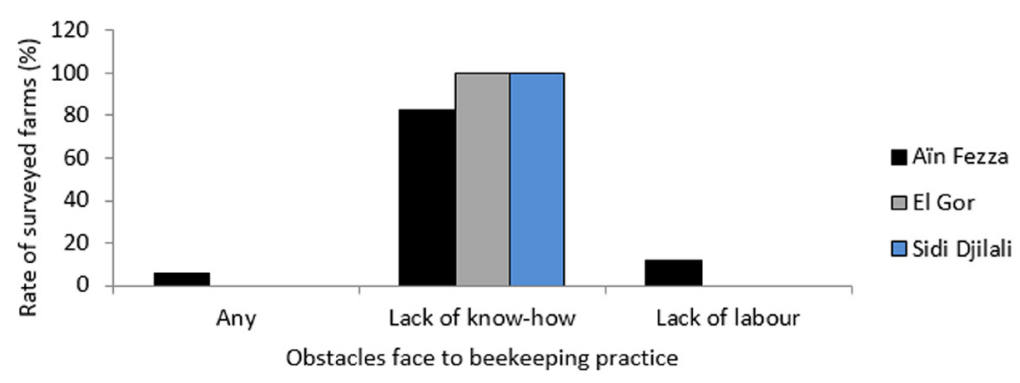

Figure 9. Obstacles face to beekeeping practice.

Funding for desired projects of the surveyed farms

As part of PPDRI, unlike collective projects of which financing is fully supported by state financial institutions, desired production activities of the surveyed farms which are considered as an individual projects are subjected, for its part, to a tripartite financing (bank credit, public subsidy, self-financing) of which bank cre dit is predominant (MADR, 2012). To this end, banks, even public, held by the principle of merchantability does not participate in any project only where they ensure the recovery of their funds, that is to say where the activities are profitable. Unfortunately, this is not the case in rural areas, particularly mountain 
areas which are poor and difficult. We must also add the amount of public subsidy which seems little incentive for beneficiaries of PPDRI. In this regard, the PRCHAT implemented in rural areas has raised the concerns of citizens inherent in the financing of individual projects; these concerns which lie in bank credit subjected to guarantee and in the personal contribution very difficult to constitute, represent so the two main obstacles which have been identified (MADR, 2008). A readjustment of funding factor according to the particularities of mountain areas which are poor and deprived, is therefore a necessary operation to develop agricultural activities and to generate a surplus for the market.

\section{Conclusions}

The expectations of farms, in terms of individual projects desired to be made, are closely related to the potential of each region fostering certain agricultural projects and to its constraints handicapping some others. In terms of agricultural projects that are better suited to the particularities of their regions, the heads of farms, as such, retain an innovation and analysis capacity that local authorities should know good value.

Moreover, the realization of some agricultural projects is conditioned, on the one hand, by improving technical assistance which showed very insufficient in these disadvantaged areas and, on the other hand, by readjusting agricultural projects financing according to the specificities of these mountainous areas which differ compared to other rural areas by poverty and by its difficult natural constraints.

\section{References}

Amzal, A. 2011. Diagnosis of involvement of actors in Proximity Projects of Integrated Rural Development (PPDRI): Case of Kendira town, province of Bejaia. 94 p. (M. Sc. Thesis) - CIHEAMIAMM, Montpellier, France.

Angeliaume, A. 2011. Water: asset (and constraint) for mountain agriculture. In: Antoine, J.M., Milian, J. (Eds) Mountain between potentials and constraints. L'Harmattan, Paris, France. p. 6186.

Austin, O.C., Ulunma, A.C., Sulaiman, J. 2012. Exploring the Link between Land Fragmentation and Agricultural Productivity. International
Journal of Agriculture and Forestry 2: 30-34.

Baghdad, C. 2015. The rural society in Algeria, between the policy of renewal and the participative approach. Sociocultural Community Development and Practices 9: 43-60.

Belal, E.A., Abdallah, F.E., Qishuo, D., Abaker, M., Talha, Z. 2015. Role of animal traction in agricultural development in Zalingei area, DarfurSudan. Veterinaria 3: 22-27.

Benniou, R., Van Damme, P. 2013. Irrigated farm management in semi-arid area East Algeria. Revue Agriculture 6: 21-28.

Bensaoula, F., Bensalah, M., Adjim, M. 2005. Recent drillings in karstic aquifers of the mountains of Tlemcen. Larhyss Journal 4: 7-15.

Bensaoula, F., Derni, I., Adjim, M. 2012. Thirty years of prospect and mobilization of groundwater resources by drillings in the province of Tlemcen. Larhyss Journal 10: 91-99.

Bessaoud, O., Montaigne, E. 2009. What answers to the bed agricultural development? Analysis of past and present agricultural and rural policies. In: Abis, S., Blanc, P., Lerin, F., Mezouaghi, M. (Eds) Prospects of agricultural policies in North Africa. Options Méditerranéennes: Série B. Etudes et Recherches $n^{\circ}$ 64, CIHEAM, Paris, France. P. 5191.

BNEDER. National Office of Studies for Rural Development. 2006. Master Plan for Mountain Areas Management of Northern Algeria. Slopes map of the mountains of Tlemcen at scale $1 / 200000$.

Chaib, B., Baroudi, N. 2014. The strategy of rural development in Algeria in the framework of renewal and participatory approach. Revue algérienne de développement économique 1: 31-46.

FAO. Food and Agriculture Organization of the United Nations. 2003. Agriculture, food and water. http://ftp.fao.org/agl/aglw/docs/ agricfoodwater.pdf <Access on 21 Jul. 2015>

FAO. Food and Agriculture Organization of the United Nations. 2007. The State of the World's Animal Genetic Resources for Food and Agriculture - in brief. http://ftp.fao.org/docrep/ fao/010/a1250e/a1250e.pdf <Access on 14 Jul. 2015>

FAO, Food and Agriculture Organization of the United Nations. 2008. Water and cereals in drylands. http://www.fao.org/docrep/012/ i0372e/i0372e.pdf <Access on 16 Jul. 2015>

Jia, L., Petrick, M. 2013. How does land fragmentation affect off-farm labor supply: 
panel data evidence from China. Agricultural Economics 45: 1-12.

Kharchi, M.T.T. 2010. Proximity Projects of Integrated Rural Development and living conditions improvement of the rural population in Algeria. 58 p. (M.Sc. Thesis) - CIHEAM-IAMM, Montpellier, France.

Leitgeb, F., Funes-Monzote, F.R., Kummer, S., Vogl, C.R. 2011. Contribution of farmers' experiments and innovations to Cuba's agricultural innovation system. Renewable Agriculture and Food Systems 26: 354-367.

Lhoste, P., Havard, M., Vall, E. 2010. Animal traction. Quae-CTA-PAG, Claire Parmentier, France. 223 p.

MADR. Ministry of Agriculture and Rural Development. 2006. The Rural Renewal. MADR, Algiers, Algeria. 211 p.

MADR. Ministry of Agriculture and Rural Development. 2008. Program of human capacity building and technical assistance. National evaluation: final report. MADR, Algiers, Algeria. $118 \mathrm{p}$.

MADR. Ministry of Agriculture and Rural Development. 2010. Agricultural and rural renewal policy in Algeria. MADR, Algiers, Algeria. $7 \mathrm{p}$.

MADR. Ministry of Agriculture and Rural Development. 2011. Procedures guide for creation of new farms and livestock. MADR, Algiers, Algeria. 24 p. (Interministerial Circular MADR-MICL n 108).

MADR. Ministry of Agriculture and Rural Development. 2012. The Agricultural and Rural Renewal in operation: Review and prospects. MADR, Algiers, Algeria. $95 \mathrm{p}$.

MADR. Ministry of Agriculture and Rural Development. 2015a. Evaluation of the consolidation implementation of the rural development program. 22nd session of evaluation. MADR, Algiers, Algeria. 21 p.

MADR. Ministry of Agriculture and Rural Development. 2015b. Evaluation of activities carried out under the PRCHAT 2. MADR, Algiers, Algeria. $9 \mathrm{p}$.

Madramootoo, C.A., Fyles, H. 2010. Irrigation in the context of today's global food crisis. Irrigation and drainage 59: 40-52.

Niroula, G.S., Thapa, G.B. 2005. Impacts and causes of land fragmentation, and lessons learned from land consolidation in South Asia. Land Use Policy 22: 358-372.
Rahmouni, D. 2013. Contribution to the study of PPDRI in the province of Tizi-Ouzou: impacts on territories and actors. 146 p. (M.Sc.) - University of Tizi-Ouzou, Tizi-Ouzou, Algeria.

Saito, K., Linquist, B., Keobualapha, B., Shiraiwa T., Horie, T. 2006. Farmers' knowledge of soils in relation to cropping practices: A case study of farmers in upland rice based slash-and-burn systems of northern Laos. Geoderma 136: 64-74.

Sofo, A., Manfreda, S., Fiorentino, M., Dichio, B., Xiloyannis, C. 2008. The olive tree: a paradigm for drought tolerance in Mediterranean climates. Hydrology and Earth System Sciences 12: 293-301.

Souidi, Z., Bessaoud, O. 2011. Development of the rural areas in Algeria: a new participatory strategy. New Medit 10: 17-24.

Vandamme, E., D'Haese, M., Speelman, S., D'Haese, L. 2010. Livestock against Risk and Vulnerability: Multifunctionality of Livestock Keeping in Burundi. In: Swanepoel, F., Stroebel, A., Siboniso Moyo, S. (Eds.) The Role of Livestock in Developing Communities: Enhancing Multifunctionality. Bloemfontein, South Africa. p. 107-121.

Zaghib, M. 2009. Evaluation and impacts of Proximity Projects of Rural Development (PPDR) on agriculture and local rural development. Case of northern mountain areas of the province of Setif. 173 p. (M.Sc. Thesis) - University of Setif, Setif, Algeria. 